\title{
FORENSIC IDENTIFICATION OF BLOOD TYPES IN PEAR (Pyrus bretschneideri) FRUIT BITEMARK
}

\author{
Andika Aliviameita', Mieke Sylvia MAR², Ahmad Yudianto ${ }^{3}$ \\ ${ }^{1}$ Master of Forensic Science Universitas Airlangga, Medical Laboratory Technology Department, Faculty of Health \\ Sciences, Universitas Muhammadiyah Sidoarjo, ${ }^{2}$ Department of Forensic Odontology, Faculty of Dental Medicine, \\ Universitas Airlangga, ${ }^{3}$ Department of Forensic Medicine and Medicolegal, Faculty of Medicine, Universitas \\ Airlangga, Surabaya Indonesia.
}

\section{ABSTRACT}

Blood type in saliva can be examined through bitemarks on an object left at the crime scene in a crime case as a screening test of suspected perpetrators. Saliva deposited at the bite contains glycoproteins which can carry blood type ABH antigens expressed in the salivary glands and excreted in saliva. Salivary examination is influenced by various external factors that damage saliva, one of which is the duration of exposure to room temperature in a certain period of time. This study aimed to determine differences in protein levels and blood group agglutination titers in (Pyrus bretschneideri) pear bitemark saliva during room temperature exposure within 30, 60 and 90 minutes. This type of study was experimental laboratories with time series design. The samples used were 18 pear bitemarks from 6 individuals who had blood groups $A, B$ and $A B$ then incubated for 30, 60 and 90 minutes. Analysis of protein content using trizol reagent was determined spectrophotometrically, while blood group examination used inhibition absorption method. Anova test showed significant difference between groups of 30 minutes exposure duration with 60 minutes and 90 minutes exposure group ( $P<0.05$; 95\% confidence interval). The Pearson correlation obtained the results of -0.739 , indicating correlation that the longer exposure to room temperature, the lower the protein content. The results showed that there was a decrease in salivary protein levels and blood group agglutination titers. Salivary protein levels were still detected in the time range of 30 , 60 and 90 minutes, so that blood type can still be examined from saliva in bitemarks on pear fruit.

Keywords: Saliva; protein; blood group; bitemark; pears (Pyrus bretschneideri)

ABSTRAK

Golongan darah pada saliva dapat diperiksa melalui bekas gigitan pada suatu benda yang ditinggalkan di TKP pada suatu kasus kejahatan sebagai uji skrining terhadap pelaku yang dicurigai. Saliva yang terdeposit pada saat menggigit mengandung glikoprotein yang dapat membawa antigen golongan darah ABH yang diekspresikan dalam kelenjar ludah dan dikeluarkan dalam saliva. Pemeriksaan saliva dipengaruhi oleh berbagai faktor luar yang merusak saliva, salah satunya adalah lama paparan suhu kamar dalam rentang waktu tertentu. Penelitian ini bertujuan untuk mengetahui perbedaan kadar protein dan titer aglutinasi golongan darah pada saliva bekas gigitan (bitemark) buah pir (Pyrus bretschneideri) pada lama paparan suhu kamar dalam rentang waktu 30, 60 dan 90 menit. Jenis penelitian ini adalah eksperimental laboratories dengan rancangan time series. Sampel yang digunakan adalah 18 bekas gigitan buah pir dari 6 individu yang mempunyai golongan darah A, B dan AB kemudian diinkubasi selama 30,60 dan 90 menit. Analisis kadar protein menggunakan reagen trizol ditentukan secara spektrofotometri, sedangkan pemeriksaan golongan darah menggunakan metode absorpsi inhibisi. Uji Anova menunjukkan perbedaan yang signifikan antara kelompok lama paparan 30 menit dengan kelompok lama paparan 60 menit dan 90 menit ( $P<0,05$; $95 \%$ confidence interval). Pada korelasi Pearson diperoleh hasil -0,739, menunjukkan adanya korelasi bahwa semakin lama paparan suhu kamar, kadar protein semakin menurun. Hasil penelitian menunjukkan bahwa terdapat penurunan kadar protein saliva dan titer aglutinasi golongan darah. Kadar protein saliva masih terdeteksi dalam rentang waktu 30, 60 dan 90 menit, sehingga masih dapat dilakukan pemeriksaan golongan darah dari saliva pada bekas gigitan buah pir.

Kata kunci: Saliva; protein; golongan darah; bekas gigitan (bitemark); pir (Pyrus bretschneideri)

Correspondence: Andika Aliviameita, Medical Laboratory Technology Department, Faculty of Health Sciences, Universitas Muhammadiyah Sidoarjo, Jalan Raya Rame Pilang no. 4, Wonoayu, Sidoarjo, Indonesia. E-mail: aliviameita@gmail.com

pISSN:2355-8393 • eISSN: 2599-056x • doi: http://dx.doi.org/10.20473/fmi.v54i4.10710

- Fol Med Indones. 2018;54:269-273 • Received 12 Oct 2017 • Accepted 26 Apr 2018

- Open access under CC-BY-NC-SA license • Available at https://e-journal.unair.ac.id/FMI/ 


\section{INTRODUCTION}

Current mass media reports indicate an increase in the number of crimes in Indonesia, both violent and nonviolent. To expose the criminal or suspect of the crime, identification should be carried out. Identification is useful for determining the identity of the perpetrator for the sake of law in a judicial process. According to the 2009 Disaster Victim Investigation (DVI) guidelines (Interpol 2009), there are two types of identification, namely primary and secondary identification. Primary identification includes examination of teeth, fingerprints and Deoxyribonucleic Acid (DNA), while secondary identification includes medical and property. One secondary identification that is needed for the initial examination as a screening test for the perpetrator is blood type. Blood type examination can be done in a short time but the results are accurate (Alqadri et al 2016). The liquid that is often found in the bodies of crime victims and also as evidence found on the crime scene is saliva, both wet and dry. The saliva found can come from the bitemark of food left by the perpetrator at the scene (Motghare et al 2011). In the murder case of national painter Basuki Abdullah, the perpetrator who killed his victim left food left in the form of bitemark. Bitemark may be used as evidence and can help expose the murderer (Lukman 2006).

The saliva contained in the perpetrator's bite marks can be used as a guide to determine the identity of the offender. One of them is by examining blood types as a screening test for the perpetrators or pursing the perpetrators of several suspects as suspects. Saliva deposited at the time of biting can be used as an alternative check for blood type analysis in the bitemark because saliva contains protein, which is glycoprotein which can carry blood type $\mathrm{ABH}$ antigens expressed in the salivary glands and removed in saliva. Individuals who have the ability to excrete blood type antigens that are identical to their red blood cells in all their body fluids (saliva, tears, sweat, urine, gastric fluid, etc.) are called secretors (Campi et al 2012). The reported percentage of secretors is around $80 \%$ and $20 \%$ for nonsecretors. In general, patterns of glycosylation and $\mathrm{ABH}$ blood group antigen expression are genetically diverse and are determined by $\mathrm{ABH}$ genes, secretor (Se) and Lewis (Le) genes, and genetic frequencies that differ between ethnic groups (Kim et al 2002).

Salivary examination is influenced by several external factors that can damage the protein in saliva, one of which is the duration of room temperature exposure at certain time which can damage the protein structure, release of disulfide bonds and inactivate the enzymatic function of the protein (Haque \& Adhikari 2015). A study in Germany showed that human saliva dries after
1 hour 40 minutes at room temperature and with various other factors, saliva will dry in less than 3 hours (Jellinghaus et al 2015). Whereas, the examination of blood type using saliva immediately showed the right results (100\% suitability), but in saliva stored for 1 hour at $15^{\circ} \mathrm{C}$ there was a decrease in the suitability of the results to $80 \%$ (Astisia 2007).

A bitemark can confirm the identification of the perpetrator, the time and age of the bitemark, an estimate of the amount of energy that is mobilized for biting and the pain suffered and the physical description of the perpetrator's teeth (Dorion, 2011). Blood type analysis on bitemark can be done on certain fruits only, mainly influenced by the water content in the fruit. Pears are chosen as research objects because these fruits are commonly consumed by the Indonesian people and easily available. To determine the decrease in protein levels under room temperature exposure and its effect on the suitability of blood type examination results, observations of saliva were performed within 30,60 and 90 minutes.

\section{MATERIALS AND METHODS}

This was laboratory experimental study with the time series design. The research sample used in this study was 18 pear bitemarks from 6 individuals who had blood groups A, B and AB then incubated at 30, 60 and 90 minutes. The concentration of protein content was determined using a spectrophotometer at a wavelength of $280 \mathrm{~nm}$, while a wavelength of $260 \mathrm{~nm}$ was used to correct the possibility of contamination by nucleic acids. The absorbance ratio of 280/260 was used to determine the correction factor. Protein levels were determined based on the formula: A280 x correction factor $\mathrm{x}$ dilution. Examination of blood type ABO absorption inhibition method was carried out by antisera dilution on the drip plate. The antisera is diluted six times, from 1:2 to $1: 64$ (holes 2 to 7 ). Furthermore, saliva swabs which were soaked in distilled water for 24 hours were added and centrifuged and then incubated. After that, $2 \%$ red blood cell suspension was added and incubated again. The results were determined by indentifying at the agglutination titer that occurred at any time of dilution.

Protein content analysis research was carried out at the Human Genetic Institute Laboratory of Tropical Disease, Campus C, Universitas Airlangga. Whereas, the examination of blood type inhibition absorption method was carried out in the Forensic Medicine Installation Laboratory of the Dr. Saiful Anwar Hospital, Malang. 
Data from research results on blood levels of protein and agglutination titers were analyzed descriptively. Repeated Anova statistical test and Pearson correlation were carried out between the length of exposure to room temperature and salivary protein levels.

\section{RESULTS}

Samples were obtained from six pear bitemarks by six individual subjects whose blood type was known. In the results of the study there were 18 samples with protein content between $0.329 \mathrm{mg} / \mathrm{ml}$ to $2.110 \mathrm{mg} / \mathrm{ml}$. The results of protein levels in pear bitemark saliva in swabs 30 minutes after biting ranged from $0.702 \mathrm{mg} / \mathrm{ml}$ to $2.110 \mathrm{mg} / \mathrm{ml}$, in swabs 60 minutes after biting ranged from $0.333 \mathrm{mg} / \mathrm{ml}$ to $1.203 \mathrm{mg} / \mathrm{ml}$, and in swabs 90 minutes after biting ranges from $0.329 \mathrm{mg} / \mathrm{ml}$ to 0.961 $\mathrm{mg} / \mathrm{ml}$. Mean protein content (Table 1) obtained at 30 minutes after the bite was $1.217 \mathrm{mg} / \mathrm{ml}$, at 60 minutes after the bite was $0.727 \mathrm{mg} / \mathrm{ml}$ and at 90 minutes after the bite was $0.603 \mathrm{mg} / \mathrm{ml}$.

Table 1. Results of mean salivary protein levels

\begin{tabular}{ccc}
\hline No & $\begin{array}{c}\text { Time of exposure to } \\
\text { room temperature }\end{array}$ & $\begin{array}{c}\text { Mean salivary protein } \\
\text { levels }(\mathrm{mg} / \mathrm{ml})\end{array}$ \\
\hline 1 & 30 minutes & 1.217 \\
2 & 60 minutes & 0.727 \\
4 & 90 minutes & 0.603 \\
\hline
\end{tabular}

Decrease in protein levels obtained at 30 minutes, 60 minutes and 90 minutes after bite can be seen in Fig. 1 . There was significant decrease between protein levels of 30 th minute swab results with protein levels of swab in the 60th and 90th minutes .

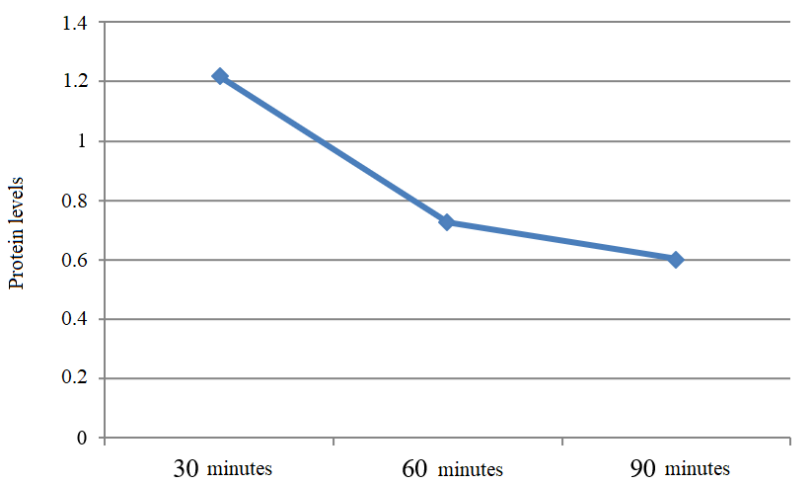

Fig. 1. Decreased salivary protein levels at 30,60 and 90 minutes.

Blood type examination with inhibition absorption method (Table 2) in swabs 30 minutes after bite showed positive agglutination values on 1:2 titers as much as
$100 \%$ of the sample. In swabs 60 minutes after the bite, the value of agglutination on titer $1: 2$ was $83.33 \%$ and 1:4 titer was $16.67 \%$. In the swab 90 minutes after the bite, the value of agglutination was obtained at 1:2 titers as much as $50 \%$ of samples, titers of $1: 4$ as much as $33.33 \%$ of samples and titers of $1: 8$ as much as $16.67 \%$ of the sample.

Table 2. Results of ABO blood type examination agglutination titers

\begin{tabular}{ccccc}
\hline No. & $\begin{array}{c}\text { Time of exposure to } \\
\text { room temperature }\end{array}$ & $\begin{array}{c}\text { Titer } \\
1: 4(\%)\end{array}$ & $\begin{array}{c}\text { Titer } \\
1: 8(\%)\end{array}$ & $\begin{array}{c}\text { Titer } \\
1: 16(\%)\end{array}$ \\
\hline 1. & 30 minutes & 100 & 0 & 0 \\
2. & 60 minutes & 83.33 & 16.67 & 0 \\
3. & 90 minutes & 50 & 33.33 & 16.67 \\
\hline
\end{tabular}

Microscopic agglutination results can be seen in Fig. 2, which shows positive agglutination results of $1(+)$ in 1 : 8 , positive $2(++)$ titers in $1: 4$ and positive $3(+++)$ titers in titer $1: 2$

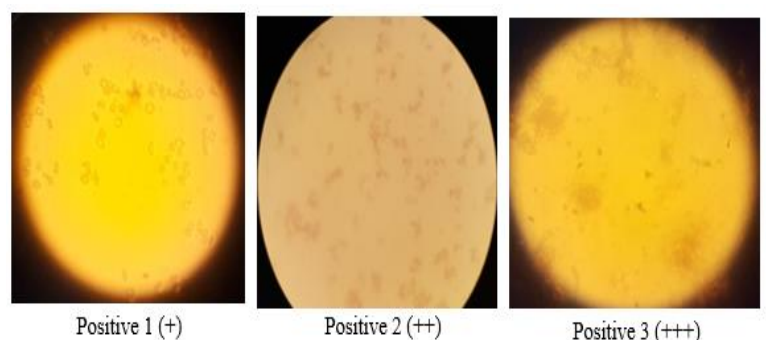

Fig. 2. Microscopic results of blood group agglutination.

Statistical test of protein content results due to long exposure to room temperature data obtained showed that data were normally distributed with a significance value $>0.05$ so that a comparative test could be carried out using Repeated Anova. In the Repeated Anova test, significance probability value of $0.043<0.05$ was obtained, indicating that there were significant differences in protein levels between room temperature exposure time. However, the Post Hoc test showed significant difference between the 30 minutes room temperature exposure duration with the 90 minutes exposure duration group, with a significance value of $0.032<0.05$. Whereas, the other group of exposure did not have a significant difference with a significance value of $>0.05$.

In the Pearson correlation test, significance result of 0.014 was obtained. This means that there was relationship between room temperature exposure time and protein content in pear bitemark saliva. Correlation values of -0.566 indicated that the longer exposure to room temperature, the lower the protein content, with the value of its moderate strength. 


\section{DISCUSSION}

The decrease in protein content in the saliva of the bitemark of pears was caused by the presence of protein denaturation. The cause of protein denaturation is influenced by several external factors, including: temperature, time, air humidity, $\mathrm{pH}$ and so on. In addition, the water content in pears $(84 \%)$ also affects the occurrence of protein denaturation, because the higher the water content, the protein becomes increasingly unstable. Denaturation due to heat usually occurs at a temperature of $40-80^{\circ} \mathrm{C}$.

Pears have a fairly high water content $(84 \%)$, resulting in easy decay in the fruit. In Chinese study of the effect of high temperatures on the content of pears, the results showed that temperatures above room temperature (35$45^{\circ} \mathrm{C}$ ) can damage proteins in pears ( $\mathrm{Li}$ et al 2010). Storage of high temperatures causes the physiological process of pears to increase, resulting in pears undergoing the processes of respiration and transpiration. Water loss during storage not only lowers weight, but also decreases quality and causes damage. Damage to pears also affects the level of protein which decreases over time.

The surface of the pear peeling due to the bite causes water to come out on the surface of the fruit. Saliva is also a liquid that is $99 \%$ water (Wong 2009). This is what causes saliva in the bite of the pear in the 90th minute at room temperature not to be drained completely, so the protein in the swab saliva on bitemark has not undergone denaturation and blood type examination can still be performed.

On examination of blood type inhibition absorption methods, all saliva samples in the bitemarks of pears showed ABO blood group antigen in saliva. Table 2 shows that saliva swab 30 minutes after the bite can be examined by $\mathrm{ABO}$ blood group by inhibition absorption method and shows $100 \%$ yield match (same as blood type examination of direct method with blood sample). In saliva swabs in the 60th minute after the bite, the suitability was reduced to $83.33 \%$. Whereas, the saliva swab examination at 90 minutes after the bite was only $50 \%$. This means that the ABO blood group antigencarrying protein in saliva still existed and had not been totally denatured in the 90th minute. This is consistent with the study of Astisia (2007) in which the examination of blood type using saliva immediately showed the right results, but there was a decrease in the accuracy of the examination results to $80 \%$ after storage of samples for 1 hour at $15^{\circ} \mathrm{C}$. Besides, it was also reinforced by Purwani (2016) study that there was a change in the secretor titre value in saliva which was examined after storage for 2 hours at $2-8^{\circ} \mathrm{C}$.
On examination of blood type the method of inhibition absorption, the occurrence of agglutination on the 1st and 2 nd hole plate drops showed positive blood type results. Invisible agglutination showed an antigenantibody reaction that occurred between saliva and antisera, and no antibodies were left to react with red blood cells, indicating blood type. Conversely, the occurrence of agglutination on the second hole drop plate until the 6th hole showed negative result of blood type. Results that showed agglutination (in the second hole to the 6th hole), both macroscopically and microscopically, indicated no antigens present in saliva which can react (neutralize) the antisera. Therefore, antisera reacted with the added red blood cells, indicating that there was no blood group in the saliva. The inhibition absorption method showed negative (-) results in blood type $\mathrm{O}$ individuals and non-secretor type individuals.

\section{CONCLUSION}

The length of exposure to room temperature has been shown to affect protein levels and agglutination of blood groups in the bite saliva in pears and obtained significant differences in protein levels between the 30minute long exposure group and the 90-minute exposure group.

On examination of blood type inhibition absorption methods, all saliva samples in the bite marks (bitemark) of pears showed ABO blood group antigen in saliva. However, there was a change in blood group agglutination titers at room temperature exposure in a period of 60 minutes and 90 minutes.

Saliva swab 30 minutes after the bite showed $100 \%$ yield match. But at 60 and 90 minutes after the bite the suitability was reduced to $83.33 \%$ and $50 \%$ only. This shows that all research subjects were secretor-type individuals, but the levels of $\mathrm{ABO}$ blood group antigencarrying proteins in saliva decreased, affecting the suitability of the results of their blood group.

\section{REFERENCES}

Alqadri, Rofinda ZD, Susanti R (2016). Gambaran golongan sekretor dan nonsekretor yang diperiksa melalui saliva mahasiswa pendidikan dokter Fakultas Kedokteran Universitas Andalas. Jurnal kesehatan Andalas 5, 20-24

Astisia T (2007). Studi perbandingan hasil pemeriksaan golongan darah terhadap sampel saliva segera dan sampel saliva yang disimpan selama 1 jam pada 
temperatur $15^{\circ} \mathrm{C}$. An unpublished thesis. Jakarta, Universitas Indonesia

Campi C, Escovich L, Moreno A, Racca L, Racca A, Cotorruelo C, Biondi C (2012). Expression of the gene encoding secretor type galactoside 2 a fucosyltransferase (FUT2) and ABH antigens in patients with oral lesions. Med Oral Patol Oral Cir Bucal 17, e63-8

Dorion RBJ (2011). Description of the bitemark, In: Bitemark evidence, a color atlas and text. 2nd ed. USA, CRC press, p 53-64

Haque MA, Adhikari B (2015). Drying and denaturation of proteins in spray drying process. Handbook of Industrial Drying. 4th ed. New York, CRC Press

Interpol (2009). Disaster victim identification guide. Available from http://www.interpol.int $>$ files $>$ DVI. Accessed May 2017

Jellinghaus K, Blässer L, Scheller C, Bohnert M (2015). Drying time for human saliva. Arch Kriminol 235, 99109
Kim W, Kim YK, Chung SC, Lee SW, Kho HS (2002). Detection of $\mathrm{ABH}$ blood group antigens in the saliva of Koreans and their stability according to storage of saliva samples. Forensic Science International 129, 58-63

Li Y, Zhang J (2010). Effect of high-temperature stress on the activity of key enzymes in the Asa-GSH cycle in Yali pears. 4, 463-467

Lukman D (2006). Buku ajar ilmu kedokteran gigi forensik. 2nd ed. Jakarta, Sagung Seto

Motghare P, Kale L, Bedia AS, Charde S (2011). Efficacy and accuracy of ABO blood group determination from saliva. Journal of Indian Academy of Oral Medicine and Radiology 23, 163-167

Purwani H (2016). Pengaruh waktu penyimpanan spesimen saliva terhadap titer status sekretor. An unpublished thesis. Poltekkes Bandung

Wong DT (2009). Salivary diagnostic. USA, NIH Public Acess, p 27-34 